Article

\title{
Integrated Approach to Sustainable Land Use Management
}

\author{
Zita Izakovičová ${ }^{1}$, Jana Špulerová ${ }^{1, *}$ (i) and František Petrovič ${ }^{2}$ \\ 1 Institute of Landscape Ecology of the Slovak Academy of Sciences, P.O. Box 254, Štefanikova 3, \\ 81499 Bratislava, Slovakia; zita.izakovicova@savba.sk \\ 2 Department of Ecology and Environmentalist, Faculty of Natural Sciences, Constantine the Philosopher \\ University Nitra, Tr. A. Hlinku 1, 94901 Nitra, Slovakia; fpetrovic@ukf.sk \\ * Correspondence: jana.spulerova@savba.sk; Tel.: +421-2-2092-0341
}

Received: 21 December 2017; Accepted: 27 February 2018; Published: 1 March 2018

\begin{abstract}
This article presents the integrated approach to sustainable land use management based on the assessment of land use and related land cover changes. Land use changes are conditioned by human activities producing changes in landscape cover and initiating processes which cause many environmental problems. It is therefore important to determine the drivers and causality of landscape changes which can then be negated to ensure sustainable land use management. The integrated landscape research approach is based on understanding landscape as a geo-ecosystem with natural, human, cultural, and historical potential. Our aim is to define the aspects of land use management which can regulate social development. The proposal for optimal land use is based on the interaction between natural capital, represented by the supply of natural regional resources and environmental conditions as well as demand represented by community need for development. The conflict between the supply of natural capital and demands lacking respect for landscape resources is an important determining factor in environmental and human problems. The integrated approach is focused on long-term rational utilization of the natural and cultural-historical resources, urban development, and the elimination of current environmental and socioeconomic problems as well as the prevention of new ones. Multi-criteria analysis is required for final environmental decision-making.
\end{abstract}

Keywords: land use; land cover; sustainable landscape management; geo-ecosystem; environmental problems; landscape processes

\section{Introduction}

Sustainability is an essential precondition for the continued existence of human society. The issue of sustainable land use has increasing importance because of accumulated environmental problems. These include increased demand for natural resources, climate change, regional climate extremes, the threat of environmental pollution, biodiversity loss, disturbed landscape stability, economic globalization, energy security, water supply, and increasing conflicts between sociocultural, political-economic, and environmental goals [1,2].

Approaches and definitions of sustainable land use development on a global scale are numerous, heterogeneous, and based on a variety of aspects. The most frequently quoted definition is the Brundtland Report's "Our Common Future"- "development that meets the needs of the present without compromising the ability of future generations to meet their own needs" [3]. Sustainability is the foundation of today's leading global framework for international cooperation described in the 2030 Agenda for Sustainable Development and its Sustainable Development Goals (SDGs) [4]. Most definitions stress that sustainable development requires socioeconomic development which preserves the principles of sustainable land use and respects the natural and cultural-historical 
resources and potential of the territory [4-6]. The focus of our research should especially support two of the latest SDG specifics for sustainable land use: (i) goal 15 "Life on land" and (ii) goal 11 "Sustainable cities and communities"; as sustainable land use contributes to halting and reversing land degradation and natural hazards, it also halts biodiversity loss and supports landscape stability. The outputs of the proposal can be applied in spatial and urban planning. Requirements for sustainable land use management issue from:

- the need to ensure and improve spatial stabilization of the territory. The stated criterion here is the demand to achieve biological balance in the country;

- needs for nature protection and rational utilization of natural resources; in particular, the protection of the land, water, forests, and gene pool;

- needs for the protection of cultural and historical resources;

- needs for the regeneration of human resources and the protection of human health;

- demands on the humanization and aesthetic appeal of the landscape.

These requirements incorporate the fundamental principles of sustainable societal development. Sustainable development accentuates caring for the Earth by putting sustainable living principles into practice and integrating conservation and development: the conservation to maintain human actions within the Earth's capacity and the development to enable people everywhere to enjoy long, healthy, and fulfilling lives [7].

Land use and land cover are interconnected, as land use initiates land cover changes [8]. Land cover is continually transformed by anthropogenic land-use influences on the properties, processes, and components of service provision. Changes in land use or management will therefore change service supply, not only for specific services but for the complete array of services provided by that (eco)system [9]. It is therefore important to study not only land use and land cover changes, but also to assess all drivers of land use change; the position and correlation of landscape elements; causality and the consequence and impacts of such changes. The main driving forces of land use are political, economical, cultural, technological, and natural [10-12].

It is not possible to evaluate and propose optimal land use based on one landscape parameter. We must therefore examine the relationships between the different landscape features and emphasize that all decision-making should apply an integrated approach based on understanding landscape as a geo-ecosystem. Landscape is envisaged in integrated scope, combining all layers of the following resources; the geological base, water and soil, climate, and biotic and morphometric parameters [13]. The geo-ecosystem encompasses a complex system of space, position, relief, and all other functionally interconnected physical landscape features of the geo-sphere where man and other organisms live and act. These features of each landscape elements comprise natural, semi-natural, and anthropogenic ecosystems [14,15]. Integrated approaches to sustainable land use management are therefore based on assessing the natural capital and human interaction aspects of landscape structure using appropriate landscape evaluation approaches, as well as multi-scale analysis and modeling [10,13-19]. The effects of individual land use changes over a particular time period determine a study area's rate of sustainability of coexistence between nature and social subsystems. Sustainable land use management must be based on integrated landscape research in the three basic dimensions: environmental, social, and economic. Moreover, analysis of connections and dependencies between these dimensions should aim to define the type of management that will regulate socioeconomic land use development and maintain its natural, human, cultural, and historical potential.

The aim of this study is to develop an integrated approach to sustainable land use management based on the understanding of landscape as geo-ecosystem including different landscape features. The focus is on long-term rational use of the natural and cultural-historical resources, the elimination of current environmental and socioeconomic problems, and the prevention of new ones. These approaches are generally well-recognized, but their application to land use has been inadequate. The specific goals concentrate on developing a method of decision-making for sustainable land use based on 
limit-setting, establishing the degree of anthropogenic changes, and identifying the type and intensity of environmental problems in a given territory. Determination of these specifics leads to proposals for eliminating the negative factors that influence the area. This methodological approach is applied in the case study of the Trnava region of Slovakia.

\section{Methods}

\subsection{Methodological Approach}

The integrated approach to sustainable land use management is a coherent system of interrelated steps, which can be modified based on the type and scale of the study area. The methodology focuses on decision-making processes based on confrontation and subsequent proposal for harmony in (1) the supply of landscape properties as natural capital and complex natural resources and (2) the demands and influences of human activities (Figure 1).

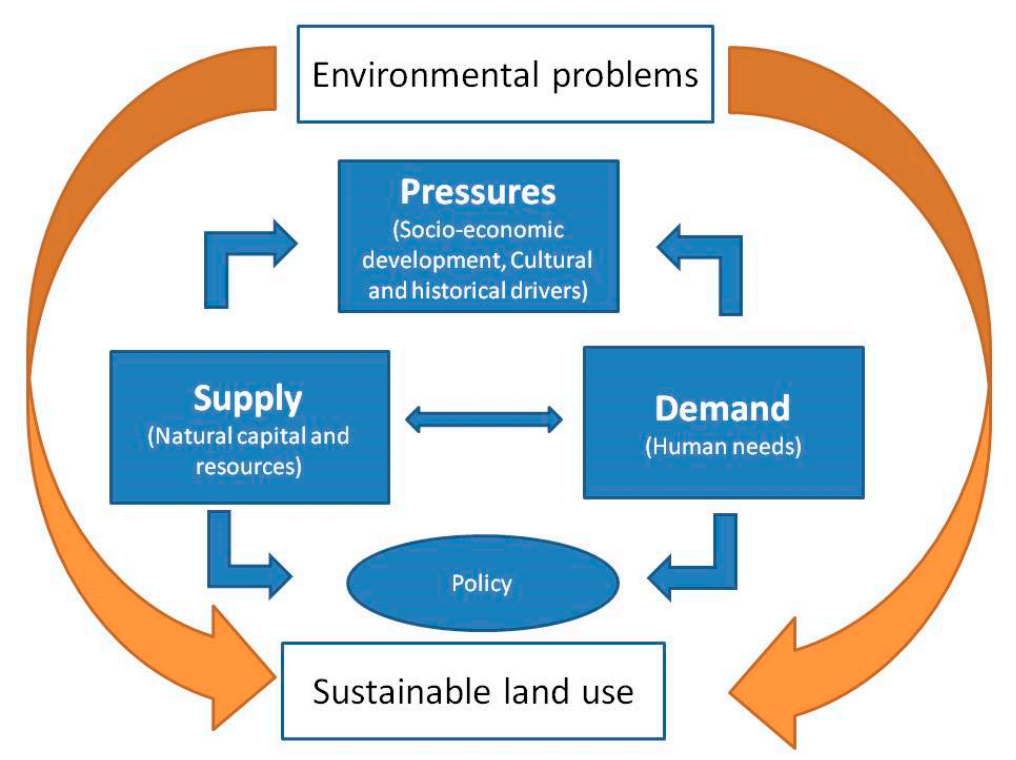

Figure 1. Integrated approach to sustainable land use management.

The approach for applying sustainable land use is therefore based on the methodology of landscape ecological planning [7] (Figure 2). This is one of Agenda 21's recommendations for the integrated protection of natural resources, and has the following steps:

\section{Analysis}

The principal objective of analysis is to choose, quantify, and describe the main features of landscape elements which define and map the abiotic, biotic, and socioeconomic features of a given territory. The most important analyses are:

- analysis of geomorphological features, geological, hydrological, soil, and climatic conditions. This establishes the properties of abiotic complexes in the territory.

- analysis of fauna and flora and their conditions determines the properties of the biotic complexes.

- analysis of the socioeconomic activities and their negative influences supplies the properties of the socioeconomic complexes.

Data was obtained from several databases, sectoral statistics, and available mapping sources. These features can have different relationships to individual human activities which support their development or restrict or limit it. It is necessary to initially concentrate on the basic selection 
of landscape features which definitively influence the location of human activities in a given area. Our choice is inextricably bound to the aims of the task, the degree of processing, and the specifics of the territory. This then provides maps in ArcGIS 10.1., which identify the abiotic, biotic, and socioeconomic conditions of the study area.

Specification of human activities requires detailed analysis of the demands of all forms of human activity on the landscape. These include all activities involved in industry, agriculture, forestry, water economy, urban development, tourism, and nature protection. It is also necessary to specify the results and risks associated with their performance. Miklós and Izakovičová [20] stress the performance of the following individual activities in the landscape:

- areas used for building construction and complexes, industrial and agricultural complexes, and communication lines and facilities.

- $\quad$ extensive use of the landscape for agriculture and forestry.

- definition of functional zones and protected areas. These include recreational zones and areas protected for soil and water resources and nature.

- The pressures connected with the performance of these activities can also initiate atmospheric pollution and soil and water contamination.

\section{Synthesis}

Synthesis involves the interaction of individual features which create homogeneous areas with different combinations of abiotic, biotic, and socioeconomic features fully integrated in the regional geo-ecosystem. Synthesis herein is achieved by the spatial superimposition of GIS analytic maps.

\section{Evaluations}

Evaluation establishes the regulations for specific human activities through justification and limit-setting on landscape elements and features involved in human activities. Discrete knowledge of regional landscape vulnerability and specification of regulated environmental limits and restrictions create the basis for decisions to permit specific human activities in a given area, to accept them with provisos, or to exclude them entirely [21]. Comparative research into spatial planning systems typically adopts a structural/legal approach and an integrated perspective embracing system structure and concrete planning practices. Sensitive discourse on planning theory towards culturally-oriented interpretation lies at the heart of appropriate decision-making [22]. The expression of spatial limits confronts landscape ecological complexes with proposed human activity. This enables the mapping of regulations for spatial limits and restrictions on the development of human activities. The limiting values of different landscape features occur in different combinations, where limiting and restricting values from any given combination determine the possibility and advisability of locating a particular activity in a given area. If one landscape feature is above the limit, the particular activity is not possible in the given area. Superimposition of the limiting values of all chosen features provides a comprehensive map of limits which decides:

- activities possible in the given area. This includes multiple ranking of suitability from different perspectives.

- $\quad$ activities not possible in the given area.

- limits and restrictions, including a combination of limits and restrictions, required to exclude particular activities from target localities.

\section{Propositions}

The proposal for ecologically optimal land use is as follows. It is necessary to determine functions for each area not limited or restricted by landscape features. This establishes functions harmonious with 
the natural and socioeconomic conditions of the region and also satisfies societal development needs. Environmental decision-making involves the identification and comparison of different alternatives based on multiple objectives and criteria. Here, multi-criteria analysis (MCA) provides the framework for integrating factual information on stakeholders' preferences, values, and associated impacts. MCA is increasingly used in combination with GIS spatial multi-criteria analysis (SMCA) [23].

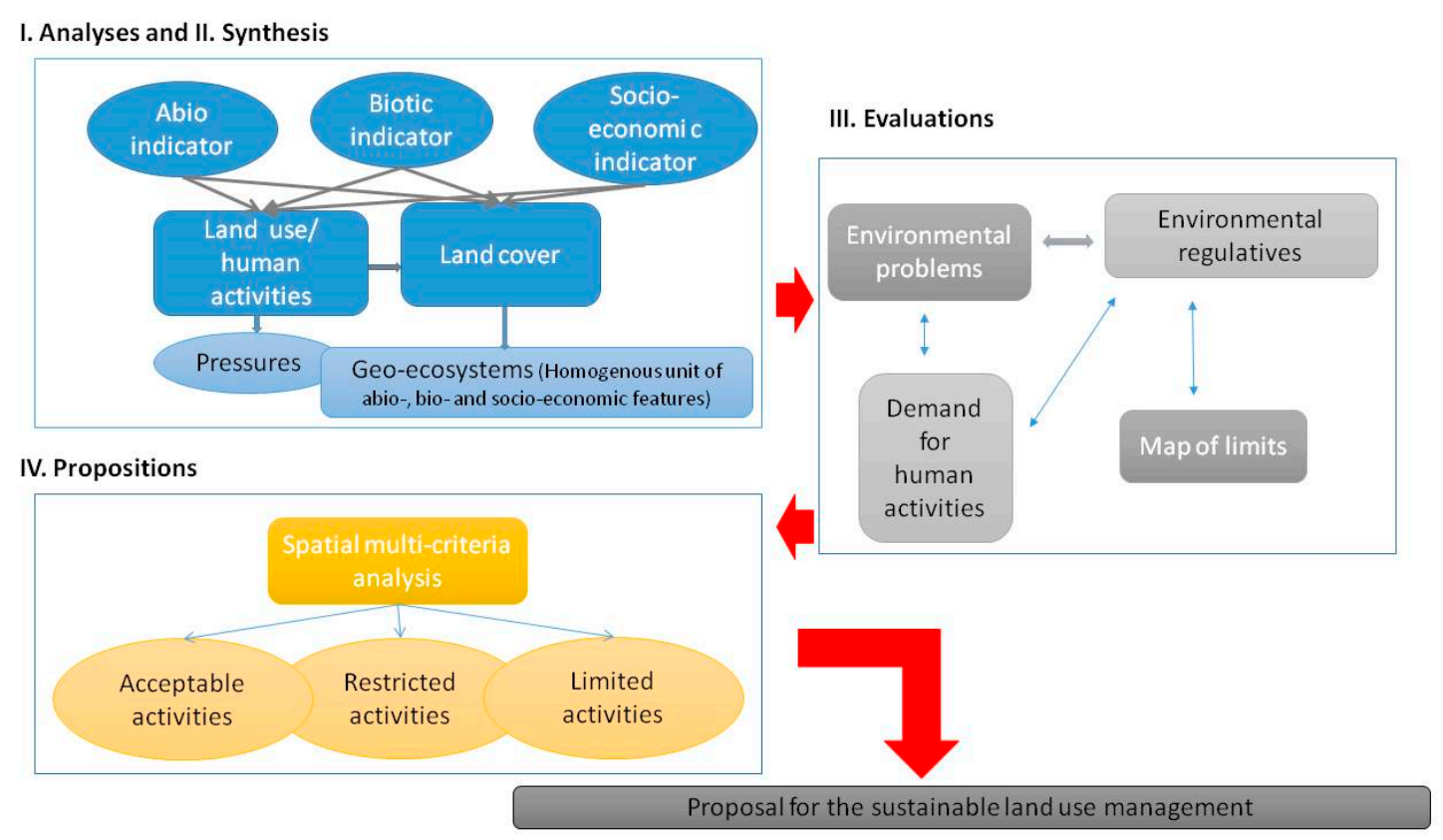

Figure 2. Methodological approach for sustainable land use management.

\subsection{Study Area}

The Trnava study area (Figure 3) has typical western Slovak agricultural landscape. Administratively, it consists of the Trnava town, surroundings, and 45 village areas. This covers $741 \mathrm{~km}^{2}$ with 131,167 inhabitants, thus ranking as a medium-sized Slovak district.

Agricultural land covers 53,107 ha and $71.6 \%$ of the district area as the dominant landscape element. Up to $93.1 \%$ of this is intensively utilized as large-block arable land, with cereals dominating the central and south part of the study area. Forests cover 13,190 ha, 17.7\%, and these areas are mainly in sub-mountain villages in the northern part of the area under the Small Carpathian Mountains (Malé Karpaty) Protected Landscape Area. Industrial sites are mainly situated in the Trnava township surroundings, where Peugeot and Samsung complexes have recently been constructed with good transport accessibility and proximity to the capital, Bratislava. 


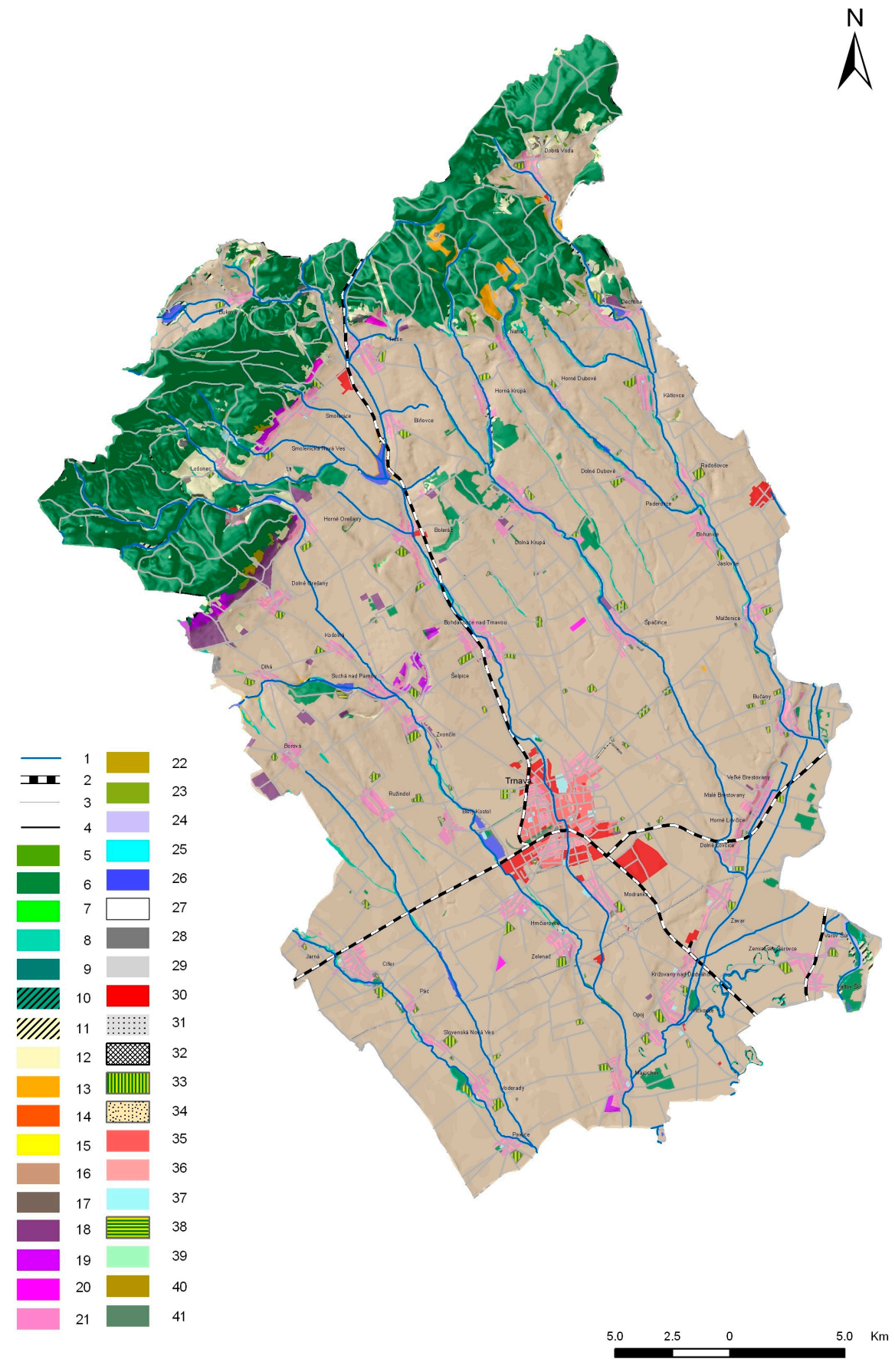

Figure 3. Land use of the study area. Legend: 1 . Water flows; 2. Railways; 3. Roads; 4. Highways; 5. Forests; 6. Semi-natural small woodland; 7. Planted small woodland; 8. Riparian vegetation; 9. Lines of trees or shrubs; 10. Wetlands; 11 . Wet meadows; 12 . Extensively managed grasslands; 13. Intensively managed meadows; 14 . Intensively managed pastures; 15 . Dry grasslands; 16 . Large-block arable land; 17. Small arable fields; 18. Large-block vineyards; 19. Small-block vineyards; 20. Orchards; 21. Gardens; 22. Mosaic of arable lands and grasslands; 23. Wooded grasslands; 24 . Natural water body; 25. Channels; 26. Water reservoirs; 27. Rocks; 28. Abandoned fields; 29. Brown fields; 30. Industrial areas; 31. Mining areas; 32. Industrial pond; 33. Agricultural farms; 34. Field airport; 35. Urban areas; 36. Rural settlement; 37. Recreational zone; 38. Garden zones with cottages; 39. Cottages; 40. Abandoned areas; 41. Transport areas. 


\section{Results}

\subsection{Landscape Features and Proposed Limits}

Analysis provided a set of study area maps identifying the abiotic, biotic, and socioeconomic conditions. Superimposition then established the geo-ecosystem and allowed us to determine environmental limits. This determination enabled objective and scientific decision-making on locating human landscape activities. Limit-setting is very complex and time-consuming, because it demands a multi-disciplinary and synergistic approach. This approach normally begins with the existing natural conditions and societal norms, but when there is no established norm for a given phenomenon or human activity, this process must be assumed by collective experts' and stakeholders' evaluation. The determination of limiting values requires extensive collection of data on the operation of the landscape system as a complex while acknowledging its individual features. This is essential, because the implementation of human activity without conflict depends on the wide variety of environmental conditions where the activity is performed.

We divided the set of regulations enforcing limits and restrictions into the following categories:

A. Abiotic regulations are based on abiotic complexes including geo-mechanical, hydrological, aerodynamic, and soil limitations. The limits have a permanent character including the relative stability of the geological substratum and local climate, and these cannot be easily changed by technology.

B. Biotic regulations are based on the biotic complexes required by living organisms. The gene pool, biodiversity, and landscape ecological stability are threatened by pressures from human activity and land use changes.

C. Anthropogenic regulations result from the competitive requirements and demands of human activities which limit the development of other activities through negative effects or by simply occupying an area. These include technical, hygienic, protective, and other limits, and these indicators are relatively easier to change than in the preceding categories. Although anthropogenic regulations are applied to very serious hygienic and environmental security demands, the limits imposed can be temporary and depend on altered circumstances.

D. Complex landscape regulations are based on the principles of landscape functioning as a complex. They include eco-stabilization, localization, carrying-capacity, behavioral, aesthetic, and cultural-historical limits. These limits are very dynamic as they result from principles of the operation of landscape as an entity and the set limits must strictly respect its historical development.

Landscape limits and restrictions are not isolated but act synergistically, so that the locality of given human activity can be limited or restricted by two or more factors. The determination of limiting and restricting factors for a given activity proceeds from the evaluation of the functional relationships between landscape elements. These center on combining the abiotic, biotic, and socioeconomic complex with requested human activity. Moreover, the process of creating regulations is most frequently performed in conjunction with decision-making tables (Table 1), and this defines three degrees of availability for performance of human activity on an area; acceptable, limited, and restricted activities. 
Table 1. Example of creation of environmental regulation based on environmental stress factors.

\begin{tabular}{|c|c|c|c|c|c|c|c|c|}
\hline $\begin{array}{c}\text { Stress Factors } \\
\text { Land Use Activities }\end{array}$ & Air Pollution & Noise Load Area & Soil Contamination & $\begin{array}{c}\text { Polluted } \\
\text { Water Flows }\end{array}$ & $\begin{array}{l}\text { Damage of } \\
\text { Vegetation }\end{array}$ & $\begin{array}{l}\text { Radio } \\
\text { Activity }\end{array}$ & Nature Reserve & $\begin{array}{l}\text { Protected Zone of } \\
\text { Water Resources }\end{array}$ \\
\hline forests $(\mathrm{F})$ & 1 & 1 & 1 & 1 & 1 & 1 & 1 & 1 \\
\hline grassland (G) & 1 & 1 & 1 & 1 & 1 & 1 & 1 & 1 \\
\hline pastures $(\mathrm{P})$ & $\mathrm{L}$ & 1 & $\mathrm{~L}$ & - & $\mathrm{L}$ & $\mathrm{L}$ & $\mathrm{L}$ & $\mathrm{L}$ \\
\hline vineyards $(\mathrm{V})$ & $\mathrm{L}$ & 1 & $\mathrm{~L}$ & - & $\mathrm{L}$ & $\mathrm{L}$ & $\mathrm{L}$ & 0 \\
\hline forage-crops (C) & $\mathrm{L}$ & 1 & $\mathrm{~L}$ & - & $\mathrm{L}$ & $\mathrm{L}$ & $\mathrm{L}$ & 0 \\
\hline arable land (A) & 0 & 1 & 0 & - & 0 & 0 & $\mathrm{~L}$ & 0 \\
\hline orchards $(\mathrm{O})$ & 0 & 1 & $\mathrm{~L}$ & - & $\mathrm{L}$ & 0 & $\mathrm{~L}$ & 0 \\
\hline gardens (GS) & $\mathrm{L}$ & 1 & $\mathrm{~L}$ & - & $\mathrm{L}$ & $\mathrm{L}$ & $\mathrm{L}$ & 0 \\
\hline recreation $(R)$ & $\mathrm{L}$ & $\mathrm{L}$ & $\mathrm{L}$ & $\mathrm{L}$ & $\mathrm{L}$ & $\mathrm{L}$ & $\mathrm{L}$ & 0 \\
\hline sport areas (S) & $\mathrm{L}$ & $\mathrm{L}$ & $\mathrm{L}$ & $\mathrm{L}$ & $\mathrm{L}$ & $\mathrm{L}$ & $\mathrm{L}$ & 0 \\
\hline medical areas $(\mathrm{M})$ & $\mathrm{L}$ & $\mathrm{L}$ & $\mathrm{L}$ & - & $\mathrm{L}$ & $\mathrm{L}$ & $\mathrm{L}$ & 1 \\
\hline housing areas $(\mathrm{H})$ & $\mathrm{L}$ & $\mathrm{L}$ & $\mathrm{L}$ & - & $\mathrm{L}$ & $\mathrm{L}$ & $\mathrm{L}$ & $\mathrm{L}$ \\
\hline farm animals (FA) & $\mathrm{L}$ & $\mathrm{L}$ & $\mathrm{L}$ & - & 0 & $\mathrm{~L}$ & $\mathrm{~L}$ & $\mathrm{~L}$ \\
\hline industrial areas (I) & 1 & 1 & 1 & - & 1 & 1 & $\mathrm{~L}$ & $\mathrm{~L}$ \\
\hline transport areas $(\mathrm{T})$ & 1 & 1 & 1 & - & 1 & 1 & $\mathrm{~L}$ & $\mathrm{~L}$ \\
\hline $\begin{array}{l}\text { Unlimited } \\
\text { activities/acceptable activities }\end{array}$ & $\mathrm{I}, \mathrm{T}, \mathrm{F}, \mathrm{G} / \mathrm{A}, \mathrm{O}$ & F, G, P, V, C, A, O, GS, I, T & $\mathrm{I}, \mathrm{T}, \mathrm{F}, \mathrm{G} / \mathrm{A}$ & $\mathrm{F}, \mathrm{G}$ & $\mathrm{I}, \mathrm{T}, \mathrm{F}, \mathrm{G} / \mathrm{A}, \mathrm{FA}$ & $\mathrm{F}, \mathrm{G}, \mathrm{I}, \mathrm{T} / \mathrm{O}, \mathrm{A}$ & $\mathrm{F}, \mathrm{G} /-$ & $\mathrm{F}, \mathrm{G}, \mathrm{M} / \mathrm{V}, \mathrm{C}, \mathrm{A}, \mathrm{O}, \mathrm{GS}, \mathrm{R}, \mathrm{S}$ \\
\hline
\end{tabular}

Legend: L—environmental limit (limited activities); 0—environmental restriction (restricted activities); 1—acceptable activities. 
The determined values and indicators which significantly limit the intensity of a given activity in an area are restrictions and not absolute exclusion. Examples here are; (1) the size of protected areas limits, but does not restrict, the development of recreational space, and (2) although agricultural production is not excluded in areas with water resource protection, its intensity is considerably restricted by recommended crop structure, chemical use, and mechanization.

\subsection{The Impact of Land Use Changes}

Landscape-ecological evaluation of current land use aims to define landscape-ecologically problem areas where the present land use does not correspond to the criteria. This identifies areas where the present land use is restricted by landscape-ecological limits. Current knowledge [24] enables us to identify the following most significant changes in the study area and interconnected problems.

- Conflicts between the socioeconomic development of nature protection; (1) building stones are extracted in the Small Carpathian Mts. Protected Landscape Area. Extraction is profitable only for entrepreneurs and the employment rate is insignificant. It is therefore deemed necessary to eliminate these mining activities in the protected areas; (2) recreational areas have been developed in the Small Carpathian Mts. and in the Trnavske rybníky fishponds Protected Area. Planned tourist attraction there can negatively affect the natural landscape and especially the avian population. This presents conflict between economical development and nature protection.

- Conflicts in socioeconomical development and natural resource protection; (1) there is competing interest in industrial development and the protection of the most fertile Trnava soils. The recent building boom has appropriated 'green fields', with the best quality soils to be used for industry, industrial parks, and housing, while many existing industrial sites lay abandoned with decreased economic value. It would be advantageous for sustainable development and regional economics if these abandoned sites were refurbished and re-used instead of expanding the industrial occupation of ecologically-valuable green fields; (2) intensive agricultural practices have led to both surface and underground water endangerment; and (3) inappropriate soil management promotes soil degradation, including compaction and erosion.

- Conflicts in nature protection and society; for example, protected areas for hygienic water resource protection and other protective zones limit the land use of some areas. These zones require essential limits in socioeconomic and urban development, including inappropriate property acquisition and utilization rights. However, unsatisfactory compensation and loss of profit create competing interests between nature protection and social justice, and this conflict requires urgent solutions.

- Conflicts in socioeconomic development and environmental quality; while industrial operators are significant employers, fundamental regional economics compete with extreme environmental load. It is currently impossible to close industries because of significant unemployment and regional economical efficiency. It is therefore essential to promote effective technology which limits contaminant production and ensures sustainable development.

\subsection{Proposal for Sustainable Land Use Management}

The aim of the proposal for optimal land use is to eliminate all problem areas, to anticipate possible new problems, and to create a structure harmonious with the territory's natural and socioeconomic conditions. Here, decision-support methods and tools such as multi-criteria analysis (MCA) and spatial multi-criteria analysis (SMCA) help achieve complex choice settings. These tools collect, organize, and analyze information which supports discussion and value elicitation and enables a better understanding of the implications of different options in sustainable land use (Figure 4). 


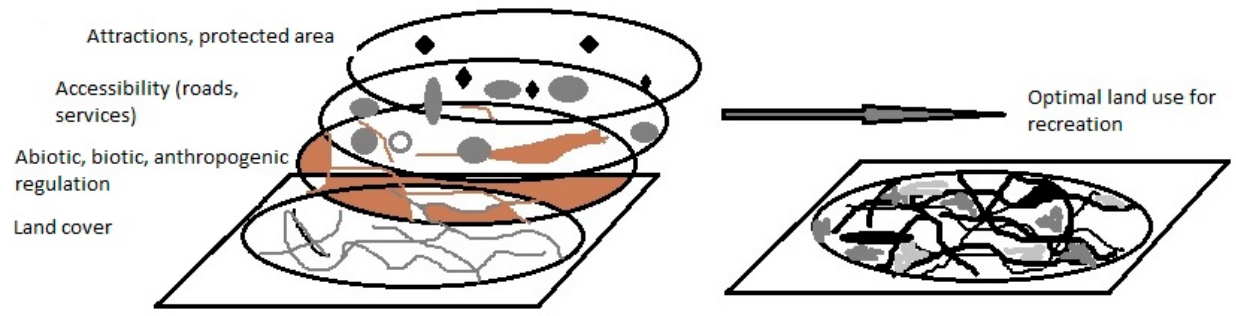

Figure 4. Example of spatial multi-criteria analysis for optimal allocated recreational activity.

We developed the proposal for sustainable land use management from analysis, synthesis, limit setting, and conflict identification (Figure 5). Moreover, we defined the following principles of limit-setting, which can be generalized for other areas:

- Abiotic conditions are the determining factors in a given area's diversity. They establish appropriate area utilization. The abiotic elements' permanent and unique attributes become determining factors in human development.

- Land use management must reduce the risk factors in sensitive localities which are otherwise predisposed to anthropogenic degradation processes including erosion, subsidence, landslides, and earthquakes.

- It is essential to support development in NATURA 2000 protected territories and ecologically valuable areas of stability. This enables scientific and medical research centers, which encourage appropriate recreational areas and reduce threats to natural landscape units.

- Similarly, the development of human activities with negative impacts must be excluded in areas where natural resources are legally protected, and explicit priority must be given to developing activities which protect individual natural resources.

- All detrimental activities must be excluded from sensitive areas with strong pressure burden. These include areas with air-pollution, soil or water contamination, and noise pollution.

- Areas without pressure loads should be maintained free from activities which can harm current living quality. These areas are suitable for high-quality living development with adequate agricultural, ecological, and recreation services.

The following outcomes result from this decision-making process:

- Selection and exclusion of activities which cannot be located on a given area because of possible landscape-ecological harm.

- Selection and restriction of activities which can be conducted on an area, but which can cause landscape-ecological damage if unrestricted.

- Selection of a hierarchy of activities which maintain the area's optimal landscapeecological function.

- Selection of complex measurements required to protect the area's nature, natural resources, and environment.

This requires the implementation of effective technology for the following: eliminating excess production of polluting substances, minimizing the allochthonous and other contaminant substance effects on environmental elements, and applying appropriate maintenance technology in agriculture and forestry. 


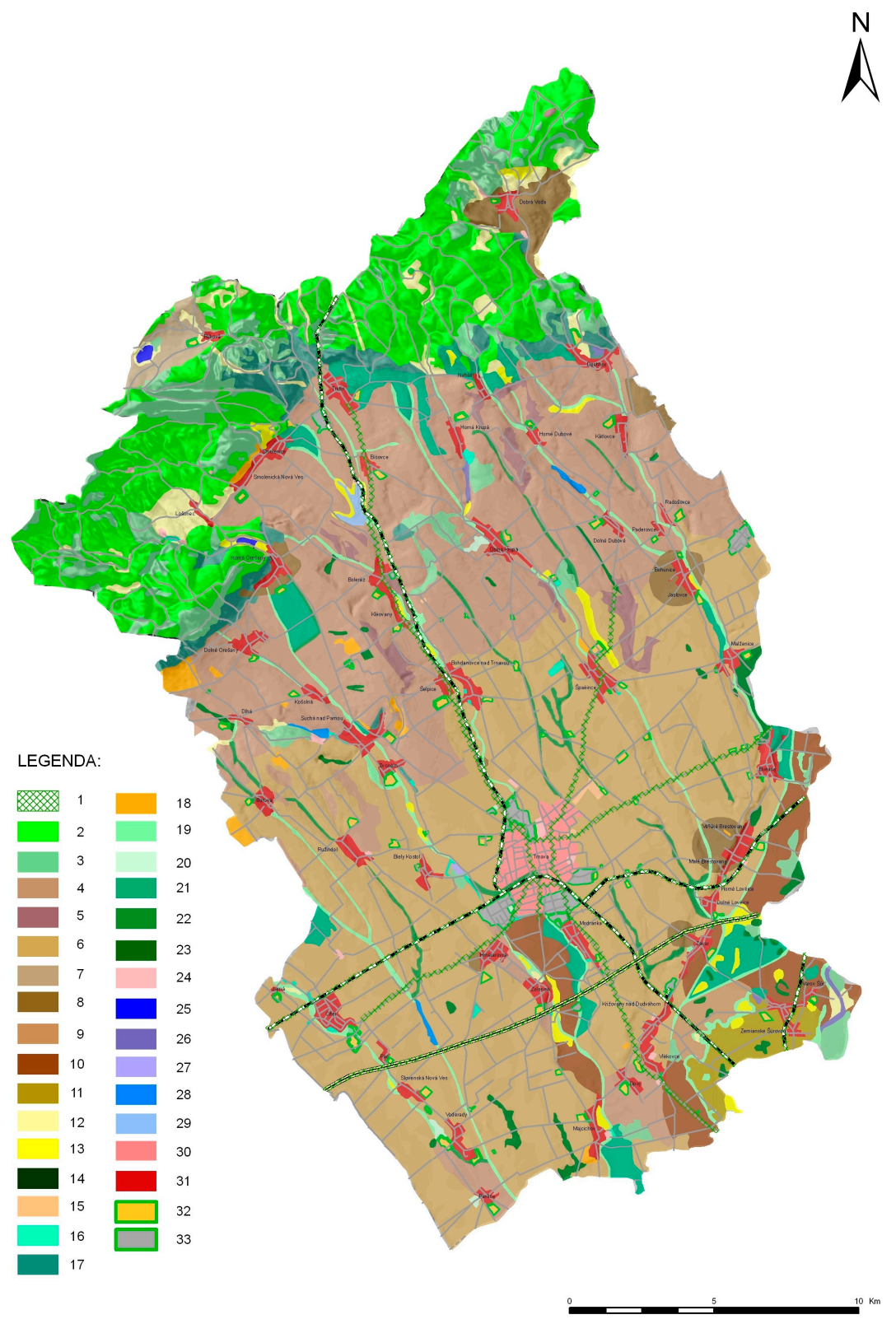

Figure 5. Proposal for optimal land use of the study area. Legend: 1. Green infrastructure of industrial zone; 2. Extensive forest management; 3 . Protected forests; 4 . Extensive agriculture—small arable fields; 5. Erosion control on small arable fields; 6 . Intensive agriculture-large-block arable lands; 7 . Extensive agriculture for protected karst areas; 8. Extensive agriculture for water protection; 9. Extensive agriculture for the protection of water resources and mineral resources; 10 . Agriculture with special management for contaminated soil; 11. Agriculture with special management for soil contamination and water protection; 12. Intensively managed meadows; 13 . Extensively managed wooded grasslands; 14. Recreational park; 15. Extensively managed grasslands; 16 . Extensive agriculture in gardens and orchards; 17. Extensive agriculture in mosaics of gardens, arable lands, and grasslands; 18. Extensive agriculture in vineyards; 19 . Water protected area-floodplain vegetation; 20 . City green infrastructure; 21. Extensive agriculture of mosaics of arable lands and grasslands; 22. Nature protection; 23. Open landscape green infrastructure; 24 . Recreation zone with cottages; 25 . Recreation zone for water sport; 26. Recreation zone for fishing; 27. Recreation zone for fishing, with nature protection restriction; 28. Water reservoir for irrigation; 29. Living area-block of flats; 30. Living area-individual houses; 31. Built-up area-agricultural buildings; 32 . Built-up area-industrial buildings; 33. Industrial zone. 


\section{Discussion}

Sustainable land use management remains a hot topic because it focuses on actual problems and ensures the integration of the natural, cultural-historical, and socioeconomical resources of a given area. Appropriate land use management arises from the necessity to solve both environmental and human existential problems. These include impacts associated with climate change, effects on health and extreme events, such as flooding, which can arise from the prevailing strategies employed in land use and protection $[25,26]$. An integrated approach to sustainable land use management helps resource users, managers, and stakeholders to manage resources sustainably by considering, reconciling, and synergizing conflicting interests and activities.

Sustainable land use management must be based on recognizing landscape as an integration of natural resources in an individual area. Each point on the Earth's surface presents a specific homogeneous entity of these combined sources. These form the landscape components and its features which satisfy human needs. Understanding the relationship between these natural resources is required to ensure sustainable land use by society. However, it is impossible to satisfy all competing aims, and dangerous to promote the land use and protection of one resource at the expense of another. An example here is the application of intensive soil use in areas with significant groundwater while ignoring the high risk of water contamination. Schulte et al. [27] support this supposition, stressing that the main global policy challenges today are the efficient and prudent use of the world's natural resources and managing the conflicting demands on land use. Labuda [28] and Surova et al. [29] add that sustainable land use must be linked with multi-functionality. This rationale addresses the interdependence of social, economic, and environmental effects of land use, with appropriate consideration of existing commodities and negative and positive external factors. Land and the rural environment provide a variety of functions, with their goods and services covering information, habitat, production, and regulation. Therefore, modifying the landscape to increase multi-functionality and reduce trade-offs with concurrent services will enhance sustainability in human-dominated landscapes [30].

The proposal for optimal land use is based on multi-criteria analysis of the natural capital, represented by the natural resources and environmental condition of the region, as well as demand represented by the community needs for development. Conflict between supply and demand which lacks respect for landscape resources is the determining factor in both environmental and human problems [31]. The proposed approach focuses on overcoming the stated difficulties by eliminating current environmental and socioeconomic problems in addition to preventing new ones. Miklos [17] agrees that this positive action will secure rational long-term utilization of natural and cultural-historical resources, and other authors [32] highlight that the proposal of eco-stabilizing elements must form part of the planned measures for both the agricultural landscape and urban areas.

The application of sustainable development principles in practice contributes to eliminating environmental problems and harmonizing intensified socioeconomical development and natural resources in a given area. This methodological approach to optimal land use has been applied in sectors of Slovakia and in other countries. The most practical result of the agricultural landscape-ecological evaluation is based on the suitability of using abiotic complexes on selected study area crops [33,34]. The conceptual framework for the quantification of supply and demand in agricultural soil-based ecosystem services is taken from Irish agriculture. This involved a case study with proxy-indicators determining the demand for individual soil functions [27]. The localizing precondition of tourism development was then evaluated using complex landscape-ecological geo-database data, land cover, selected morphometric indicators, selected town-planning, and demographical and socioeconomic indicators [35,36]. The pressures were found to be greatest on urban ecosystems, with high population density and multiple activities with different influences on the environment. These can cause unpredictable responses to environmental quality [37]. Investment in conservation, restoration, and sustainable ecosystem use are increasingly considered a "win-win situation" which generates substantial ecological, social, and economic benefits [9]. 
The optimal landscape-ecological solution for spatial land use is the major outcome of sustainable land use management. This comprises an initial proposal of the most suitable localization of demanded human activities in the given territory, and a subsequent proposal of measurements which ensure the activities' appropriate environmental functioning in that locality. This answers the questions of how and where to provide human activities in the territory that would least conflict with the natural conditions, and how to apply them in the most suitable land use management methods to reduce natural risks and hazards [38-40]. The solution to environmental problems and sustainable land use has (1) aspects of spatial organization, which provide optimal land-use, and (2) aspects ensuring technical expertise in landscape ecology.

The application of limits is most important, because they form the basis for optimal landscape-ecological decision-making processes in land use. The limits are applied to both evaluating the territory's current functional use and establishing proposals for optimal allocation and management of the many different land use options [38,41,42]. Multi-criteria decision analysis determined the multiple well-being dimensions of ecological, economic, cultural, and moral aspects of policy and management problems $[43,44]$. Complex spatial multi-criteria analysis planning with modeling then created quality outcomes which helped identify impacts on both the environment and residents. These outcomes also have an important function in the decision-making and draft measure phases which mitigate negative impacts on the environment [45].

\section{Conclusions}

This paper presents the integrated approach to land use management based on limit-setting and other regulative measures, which we developed as a basis for the decision-making process. It can be used to process development documents and strategies from the local scale of cities or municipalities to the regional scale. Integrated land use management is based on landscape research in three basic dimensions: environmental, social, and economic, as well as on examining their interrelationships and contexts. In particular, economic and social benefits are directly dependent on an organization's property including land use, ownership, and other rights, without which any planning activity in the landscape is practically impossible. Our presented method can contribute to the improvement of existing methods of land use assessment, such as land consolidation or the territorial system of ecological stability [46-48]. These methods are aimed at efficient land use and a new land arrangement in accordance with the conditions for improving the environment, soil protection, water management, increasing the ecological stability of the landscape, and improving the quality of rural life. The successful application of sustainable land use management requires multiple social measures at all levels of legislation, economic outcomes, education, and teaching. Successful sustainable development in actual practice demands the following essential measures:

- The regulations for optimal land use must be applied to sector plans-it is unavoidable that the regulated use of particular resources by production and non-production entities favors the development of one area over another and/or fails to avoid conflicts of interest.

- The principles of sustainable development should be implemented with as much population awareness as possible, especially for stakeholders and policymakers-this requirement is based on creating an effective system of education in sustainable development and land use management, because adequate education enhances public acceptance of the principles and criteria for practical sustainable development.

- To ensure the promotion of effective tools for legislative protection and economic outcomes, it is essential that legislative rules and regulations support the rational use of natural resources and protect both the environment and human health. Economic tools such as taxes, duties, and fees support both decision-making and sustainable landscape-ecological policy. Fines imposed for inappropriate land use, environmental pollution, human health endangerment or injury, and breach of regulations help eliminate environmental problems. Finally, subsidies from 
rural development programs and other sources help reduce marginality and social disparity in rural communities.

Acknowledgments: This paper is the result of funding from the Slovak Research and Development Agency (Project No. APVV-0866-12, "Evaluation of ecosystem functions and services of the cultural landscape") and Scientific Grant Agency of Ministry of Education of the Slovak Republic (No. 1/0496/16 "Assessment of natural capital, biodiversity and ecosystem services in Slovakia"). We thank Raymond Marshall for English proof-reading.

Author Contributions: The research was conceived, designed and implemented by Zita Izakovičová and Jana Špulerová. František Petrovič contributed with technical knowledge of ArcGIS and with developing methodology scheme. All authors contributed to revision of the article and have given final approval of the version to be published.

Conflicts of Interest: The authors declare no conflicts of interest.

\section{References}

1. Axelsson, R.; Angelstam, P.; Elbakidze, M.; Stryamets, N.; Johansson, K.-E. Sustainable Development and Sustainability: Landscape Approach as a Practical Interpretation of Principles and Implementation Concepts. J. Landsc. Ecol. 2012, 4, 5-30. [CrossRef]

2. Findell, K.L.; Berg, A.; Gentine, P.; Krasting, J.P.; Lintner, B.R.; Malyshev, S.; Santanello, J.A., Jr.; Shevliakova, E. The impact of anthropogenic land use and land cover change on regional climate extremes. Nat. Commun. 2017, 8. [CrossRef] [PubMed]

3. Brundtland, G.; Khalid, M.; Agnelli, S.; Al-Athel, S.; Casanova, P.G.; Chidzero, B.; Padika, L.; Hauff, V.; Lang, I.; Shijun, M.; et al. Our Common Future; Brundtland Report; Oxford University Press: Oslo, Norway, 1987. Available online: www.un-documents.net/our-common-future.pdf (accessed on 2 February 2018).

4. IISD. Sustainable Development. 2016. Available online: http://www.iisd.org/topic/sustainabledevelopment (accessed on 4 December 2017).

5. IUCN. Caring for the Earth. In A Strategy for Sustainable Living; IUCN, UNEP, WWF: Glad, Switzerland, 1991.

6. Potschin, M.; Haines-Young, R. Landscapes, sustainability and the place-based analysis of ecosystem services. Landsc. Ecol. 2013, 28, 1053-1065. [CrossRef]

7. Ružička, M.; Miklós, L. Basic Premises and Methods in Landscape Ecological Planning and Optimization. In Changing Landscapes: An Ecological Perspective; Zonneveld, I.S., Forman, R.T.T., Eds.; Springer: New York, NY, USA, 1990; pp. 233-260. Available online: http:/ /link.springer.com/chapter/10.1007/978-1-4612-3304$6 \_13$ (accessed on 8 December 2014).

8. De Sherbinin, A. A CIESIN Thematic Guide to Land-Use and Land-Cover Change (LUCC); Center for International Earth Science Information Network (CIESIN) Columbia University Palisades: Palisades, NY, USA, 2002; Available online: http:/ / sedac.ciesin.columbia.edu/guides (accessed on 28 November 2017).

9. De Groot, R.S.; Alkemade, R.; Braat, L.; Hein, L.; Willemen, L. Challenges in integrating the concept of ecosystem services and values in landscape planning, management and decision making. Ecol. Complex. 2010, 7, 260-272. [CrossRef]

10. Bürgi, M.; Hersperger, A.M.; Schneeberger, N. Driving forces of landscape change-Current and new directions. Landsc. Ecol. 2004, 19, 857-868. [CrossRef]

11. Hersperger, A.M.; Buergi, M. Driving Forces of Landscape Change in the Urbanizing Limmat Valley, Switzerland. In Modelling Land-Use Change: Progress and Applications; Koomen, E., Stillwell, J., Bakema, A., Scholten, H.J., Eds.; Springer: Dordrecht, The Netherlands, 2007; pp. 45-60.

12. Wohlmeyer, H.F.J. The unconscious driving forces of landscape perception and formation. In Sustainable Development of Multifunctional Landscapes; Helming, K., Wiggering, H., Eds.; Springer: New York, NY, USA, 2003; pp. 79-93.

13. Miklós, L.; Izakovičová, Z. Krajina Ako Geosystém (Landscape as Geo-Ecosystem); VEDA Publishing of the Slovak Academy of Sciences: Bratislava, Slovakia, 1997.

14. Braunisch, V.; Patthey, P.; Arlettaz, R.L. Spatially explicit modeling of conflict zones between wildlife and snow sports: Prioritizing areas for winter refuges. Ecol. Appl. 2011, 21, 955-967. [CrossRef] [PubMed]

15. Frost, P.; Campbell, B.; Medina, G.; Usongo, L. Landscape-Scale Approaches for Integrated Natural Resource Management in Tropical Forest Landscapes. Ecol. Soc. 2006, 11. Available online: https: / / www.ecologyandsociety.org/vol11/iss2/art30/ (accessed on 30 November 2017). [CrossRef] 
16. Falt'an, V.; Krajcirovičová, L.; Petrovič, F.; Khun, M. Detailed Geoecological Research of Terroir with the Focus on Georelief and Soil-A Case Study of Kratke Kesy Vineyards. Ekologia (Bratislava) 2017, 36, 214-225. [CrossRef]

17. Miklos, L. Landscape-ecological theory and methodology: A goal oriented application of the traditional scientific theory and methodology to a branch of a new quality. Ekologia (Bratislava) 1996, 15, 377-385.

18. Antrop, M. Why landscapes of the past are important for the future. Landsc. Urban Plan. 2005, 70, $21-34$. [CrossRef]

19. Barančoková, M.; Kenderessy, P. Assessment of Landslide Risk Using Gis and Statistical Methods in Kysuce Region. Ekologia (Bratislava) 2014, 33, 26-35. [CrossRef]

20. Jakab, I.; Petluš, P. The Use of Viewshed Analysis in Creation of Maps of Potential Visual Exposure. In GIS OSTRAVA 2013-Geoinformatics for City Transformation; Ivan, I., Longley, P., Fritsch, D., Horak, J., Cheshire, J., Inspektor, T., Eds.; Publisher VSB-TECH UNIV Ostrava: Ostrava, Czech Republic, 2012; pp. 375-390.

21. Vyskupova, M.; Pavlickova, K.; Baus, P. A landscape vulnerability analysis method proposal and its integration in the EIA. J. Environ. Plan. Manag. 2017, 60, 1193-1213. [CrossRef]

22. Reimer, M.; Getimis, P.; Blotevogel, H.H. Spatial Planning Systems and Practices in Europe. A comparative perspective. In Spatial Planning Systems and Practices in Europe: A Comparative Perspetive on Continuity and Changes; Reimer, M., Getimis, P., Blotevogel, H.H., Eds.; Routledge: Abingdon, UK, 2014; pp. 1-20.

23. Orsi, F.; Geneletti, D.; Borsdorf, A. Mapping wildness for protected area management: A methodological approach and application to the Dolomites UNESCO World Heritage Site (Italy). Landsc. Urban Plan. 2013, 120, 1-15. [CrossRef]

24. Izakovičová, Z.; Mederly, P.; Petrovič, F. Long-Term Land Use Changes Driven by Urbanisation and Their Environmental Effects (Example of Trnava City, Slovakia). Sustainability 2017, 9, 1553. [CrossRef]

25. Bastian, O. Ecosystem and Landscape Services: Development and Challenges of Disputed Concepts. In Landscape and Landscape Ecology; Halada, L., Baca, A., Boltiziar, M., Eds.; ILE SAS: Bratislava, Slovakia, 2016; pp. 215-226.

26. Izakovičová, Z.; Moyzeová, M.; Oszlányi, J. Problems in Agricultural Landscape Management Arising from Conflicts of Interest-A Study in the Trnava Region, Slovak Republic. In Innovations in European Rural Landscapes; Wiggering, H., Ende, H.-P., Knierim, A., Pintar, M., Eds.; Springer: Berlin/Heidelberg, Germany, 2010; pp. 77-95. Available online: http://link.springer.com/chapter/10.1007/978-3-642-04172-3_6 (accessed on 8 December 2014).

27. Schulte, R.P.O.; Creamer, R.E.; Donnellan, T.; Farrelly, N.; Fealy, R.; O'Donoghue, C.; O'hUallachain, D. Functional land management: A framework for managing soil-based ecosystem services for the sustainable intensification of agriculture. Environ. Sci. Policy 2014, 38 (Suppl. C), 45-58. [CrossRef]

28. Labuda, M. Multifunkčné pol'nohospodárstvo ako nástroj ekologickej ochrany kultúrnej krajiny (Multifunction Agriculture as the Instrument of Ecological Cultural Landscape Protection). Životné Prostr. 2011, $45,38-42$.

29. Surova, D.; Surovy, P.; de Ribeiro, N.A.; Pinto-Correia, T. Integrating differentiated landscape preferences in a decision support model for the multifunctional management of the Montado. Agrofor. Syst. 2011, 82, 225-237. [CrossRef]

30. Sturck, J.; Verburg, P.H. Multifunctionality at what scale? A landscape multifunctionality assessment for the European Union under conditions of land use change. Landsc. Ecol. 2017, 32, 481-500. [CrossRef]

31. Böhmelt, T.; Bernauer, T.; Buhaug, H.; Gleditsch, N.P.; Tribaldos, T.; Wischnath, G. Demand, supply, and restraint: Determinants of domestic water conflict and cooperation. Glob. Environ. Chang. 2014, 29 (Suppl. C), 337-348. [CrossRef]

32. Reháčková, T.; Pauditšová, E. Evaluation of urban green spaces in Bratislava. Boreal Environ. Res. 2004, 9, 469-477.

33. Miklós, L.; Miklisova, D.; Reháková, Z. Systematization and Automatization of Decision-Making Process in Landep Method. Ekologia ČSFR 1986, 5, 203-231.

34. Hrnčiarová, T. Abiotic complexes-An important part of ecological decision making in agricultural landscape. Ekologia (Bratislava) 2005, 24, 397-410.

35. Drábová-Degro, M.; Krnáčová, Z. Assessment of Natural and Cultural Landscape Capacity to Proposals the Ecological Model of Tourism Development (case Study for the Area of the Zamagurie Region). Ekologia (Bratislava) 2017, 36, 69-87. [CrossRef] 
36. Wade, A.A.; Theobald, D.M.; Laituri, M.J. A multi-scale assessment of local and contextual threats to existing and potential US protected areas. Landsc. Urban Plan. 2011, 101, 215-227. [CrossRef]

37. Krnáčová, Z.; Hrnčiarova, T. Landscape-ecological planning-A tool of functional optimization of the territory (case study of town Bratislava). Ekologia (Bratislava) 2006, 25, 53-67.

38. Antrop, M. From holistic landscape synthesis to transdisciplinary landscape management. In From Landscape Research to Landscape Planning: Aspects of Integration, Education and Application; Tress, B., Tres, G., Fry, G., Opdam, P., Eds.; Springer: Dordrecht, The Netherlands, 2006; Volume 12, pp. 27-50.

39. Gratton, M.; Morin, S.; Germain, D.; Voiculescu, M.; Ianas, A. Tourism and natural hazards in Balea Glacial area valley, Faragas massif, Romanian Carpathians. Carpathian J. Earth Environ. Sci. 2015, 10, 19-32.

40. Hrnčiarová, T.; Izakovičová, Z.; Miklós, L.; Lehotský, M.; Tremboš, P.; Durajková, N.; Ot'ahel', J. Environmental-Conditions of Formation and Development of Regions in Slovakia. Ekologia (Bratislava) 1994, 13, 87-94.

41. Belčáková, I.; Pšenáková, Z. Specifics and Landscape Conditions of Dispersed Settlements in SlovakiaA Case of Natural, Historical and Cultural Heritage. In Best Practices in Heritage Conservation and Management: From the World; Piscitelli, M., Ed.; Scuola Pitagora Editrice: Napoli, Italy, 2014; Volume 46, pp. 261-268.

42. Lambin, E.F.; Turner, B.L.; Geist, H.J.; Agbola, S.B.; Angelsen, A.; Bruce, J.W.; Coomes, O.T.; Dirzo, R.; Fischer, G.; Folke, C.; et al. The causes of land-use and land-cover change: Moving beyond the myths. Glob. Environ. Chang. 2001, 11, 261-269. [CrossRef]

43. Muchova, S.; Svecova, A.; Pavlickova, K.; Zelenakova, M. Evaluation of the development potential in optimisation of the area using. Ekologia (Bratislava) 2006, 25 (Suppl. 1), 179-189.

44. Saarikoski, H.; Mustajoki, J.; Barton, D.N.; Geneletti, D.; Langemeyer, J.; Gomez-Baggethun, E.; Marttunen, M.; Antunes, P.; Keune, H.; Santos, R. Multi-Criteria Decision Analysis and Cost-Benefit Analysis: Comparing alternative frameworks for integrated valuation of ecosystem services. Ecosyst. Serv. 2016, 22, 238-249. [CrossRef]

45. Pauditšová, E.; Slabeciusova, B. Modelling as a Platform for Landscape Planning. In Geoconference on Informatics, Geoinformatics and Remote Sensing; Stef92 Technology Ltd.: Sofia, Bulgaria, 2014; Volume III, pp. 753-760.

46. Sklenicka, P. Applying evaluation criteria for the land consolidation effect to three contrasting study areas in the Czech Republic. Land Use Policy 2006, 23, 502-510. [CrossRef]

47. Juskova, K.; Muchova, Z. Land Consolidation as an Instrument for Land Ownership Defragmentation. In MENDELNET 2013; Skarpa, P., Ryant, P., Cerkal, R., Polak, O., Kovarnik, J., Eds.; Mendel Univ Brno: Brno, Czech Republic, 2013; pp. 444-448.

48. Muchova, Z.; Leitmanova, M.; Petrovic, F. Possibilities of optimal land use as a consequence of lessons learned from land consolidation projects (Slovakia). Ecol. Eng. 2016, 90, 294-306. [CrossRef] 